\title{
Rural infrastructure and smallholders commercialization: analysis of crop input market from Jimma Zone, South-West Ethiopia
}

Minyahil Alemu ${ }^{*}$, Amsalu Dachito

Economics Department, Jimma University, Ethiopia

minale16@yahoo.com ${ }^{1 *}$, dachinamo@gmail.com ${ }^{2}$

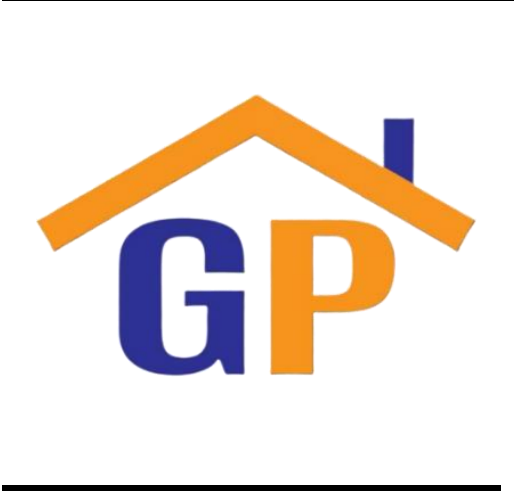

Article History

Received on 8 August 2020

$1^{\text {st }}$ Revision on 21 August 2020

$2^{\text {nd }}$ Revision on 29 August 2020

$3^{\text {rd }}$ Revision on 1 September 2020

$4^{\text {th }}$ Revision on 2 September 2020

Accepted on 2 September 2020

\begin{abstract}
Purpose: This study is aimed to examine the effect of rural infrastructure on smallholders' crop input market participation with reference to Jimma zone.
\end{abstract}

Research methodology: Censored Tobit approach was employed to model relationships between the degree of household market participation from input side and rural infrastructures.

Results: Distance to the nearest all-weather-road from the farm area was found important. Moreover, provision of rural credit, communication and rural market services was found to significantly foster smallholder commercialization. Unfortunately, we estimated trivial coefficient for agricultural extension.

Limitation: This study is limited to a year data, where we are unable to estimate the long term impact of rural infrastructural service on rural commercialization.

Contribution: Various inadequacies in the provision of services may likely be involved. The right approach for the future should consider efficiency as well as the adequacy of the services being provided. It would be better to provide smallholders with the necessary infrastructures to ensure growth as well as the transformational targets. Besides, interventions intensifying rural access to information are vital.

Keywords: Censored Tobit, Commercialization, Crop input Market index, Infrastructure, Smallholder

How to cite: Alemu, M., \& Dachito, A. (2020). Rural infrastructure and smallholders commercialization: analysis of crop input market from Jimma Zone, South-West Ethiopia. International Journal of Financial, Accounting, and Management, 2(3), 185-197.

\section{Introduction}

Commercial transformation of subsistence agriculture is indispensable to ensure economic transformation and realize the leading objective of most developing economies; i.e., industrialization. Since dominant share of these countries economy in terms of employment, foreign currency and output is accounted for agricultural sector, economic transformation is awkward unless prior transformation is attained from agriculture (Poole et al., 2013; Ogutu et al., 2017; Chirani and Effatdoost, 2013; Timmer, 1997). Besides, commercial transformation of subsistence agriculture is also vital to ensuring food security and peoples' welfare. According to (Pingali et al., 2019; Afework and Endrias, 2016; Katerega et al, 2018), commercialization of subsistence agriculture is expected to bring comparative advantage, economies of scale, exchange of knowledge as well as technological innovations. The technological innovations are further meant to reduce average costs of production among recipient countries, increasing gains from international trade and argued to bring economic growth and transformation. 
Development of rural infrastructure has been considered a precondition to enhance smallholder commercialization, both from the input and output sides. These include; rural all-weather roads, communication, credit services, agricultural extension and the like. In contrast, developing countries are characterized by inadequate provision of rural infrastructures, and it has been mentioned as the dominant constraint of agricultural growth and economic transformation in most LDCs (Katerega et al., 2018; Qaim and Ogutu, 2018; Chan et al., 2009; Stewart, 2010). Conceptually, infrastructure is argued to boost productivity in two basic ways: (i) directly; own sectorial contribution to GDP, serving as an input in the production process of other sectors; and (ii) indirectly; nurturing total factor productivity by decreasing transaction and related costs, consequently allowing an efficient use of existing inputs. Infrastructure can be described as a complementary element for transforming subsistence agriculture, and maintaining economic growth (Qaim and Ogutu, 2018; Newbery, 2012; Rosewell, 2012; Kabiti et al., 2015). Asian Development Bank revealed that, road provision gives access to market and integrates different market areas, lessens risks for which the rural poor are often exposed to. Pervasive delivery of access to all-weather roads would grant generous benefits, bulk of them going to the poor on average (Barrett, 2014; Chanyalew et al., 2011; Justus et al., 2015). How big is the contribution of rural infrastructure in the development of smallholders' commercialization from the input side? It is our leading motive in this paper, taking a random draw of households from rural Jimma.

For the last decade/or so years, Ethiopia has implemented commercialization as a strategy of achieving growth and sectorial transformation in agriculture, and the economy at large. Extensive provision of extension services, farm input and credit supply have been intensifying ominously to ensure sectorial transformation in the country, while the government remained the main actor. Significant body of evidences such as (Kabiti et al., 2015; Ogutu et al., 2017; Osmani et al., 2015) reveal that, without private sector participation in the sector, the public sector alone couldn't realize efficiency and hence transformation, both in production and distribution. Despite various efforts to that end, Ethiopian agriculture is still dominated by subsistence production, and still operated using traditional technologies. In its current pace, it's unlikely to expect growth and sectorial transformation in agriculture. Though empirical studies exist on the issues of productivity, and also considerably, on the determinants of smallholder commercialization from the output side, little attention has been given to the input side of the markets for agriculture in Ethiopia. Commercial transformation of subsistence agriculture couldn't be achieved without due consideration to the inputs market. In support of this argument, (Katerega et al, 2018; Pingali et al, 2019; Qaim and Ogutu, 2018) pointed out that, commercialization occurs from the output side with intensified market surplus, which can only be achieved through enhanced input market participation. Development of input market involves increasing size and quality of purchased inputs and relevant technology aimed to boost farm productivity. Thus, there is a need to emphasis the input side of smallholder commercialization, if the mission for commercial transformation of subsistence agriculture has to come true. Henceforth, here we aim to pave policy concern to that end. We examine the effect of rural infrastructure on smallholders' crop input market participation in Jimma zone of Oromia regional state.

\section{Literature Review and Hypothesis Development}

\subsection{Smallholder and Smallholder Commercialization: definitions}

\section{(a) The concept of smallholder/small farm}

Theoretically, the concept 'smallholder farm' is explained in relation to the farm size, nature of input usage, level of technology application and the like. In that regard, small farm is that basing on family labor, low or poor farm technology, and subsistence in nature. However, the term is conceptualized otherwise to constitute various approaches. For example, (Mtigwe et al, 2013; Justus et al., 2015) associated smallholder farm with the source of labor in which the householder farm production is based. For them, 'small farm' is a household farm operation, where all/or usually greater of the labor force engaged in the process constitutes a family member. The argument demonstrates that, there are mostly no direct labor costs in this type of farms, since everyone is making own business. The World Bank agricultural group, on the other hand, linked small farm to farm size as well wealth of the producers. The World Bank defines 'smallholder' as a farm operation in (usually) below two hectares of farm land and does not require large investment, and typically low asset based (World Bank, 2017). 
The Food and Agriculture Organization, in turn, differentiates farmers based on their resource endowment and wealth levels; and defined smallholder as those with comparatively less resource base (FAO, 2018). The latter description is somewhat implausible, as it refers to only relative performance in the sector. In reality, all in a group likely performs below standard, while individual variations also exist. Factually, all is 'under the reference point'; but on relative basis, one may be better than the other. Thus, the relative classification of farm holding is not convincing. The first two definitions, at least, took a noteworthy consideration in empirical studies. However, a conceptual challenge remained on which reference (labor versus farm size and resource endowment) base on.

In Ethiopia, there is also no clear cut conceptualization of 'smallholder' farm. However, it is obvious in the country that a greater proportion of (approximately 90 percent) the total sectorial output comes from smallholder agriculture (UNDP, 2016; CSA, 2016). The implication is that majority of the Ethiopian farm operation is characterized by smallholder agriculture. In Ethiopia, the farmer's land holding size has been a conventional approach to classify farms into scales. According to the Ethiopian Ministry of Agriculture and Rural Development (MoARD), if an average land holding size of a household farm operation is below two hectares, then it is considered as 'smallholder farm' (MoARD, 2017). We, thus, based our analysis on this national definition for smallholder agriculture.

\section{(b) Smallholder Commercialization defined}

Agricultural commercialization is also interpreted differently in agriculture and social science literature. For instance, (Chirani and Effatdoost, 2013; Dorsey, 2017) conceptualized the term 'agricultural commercialization' as "the share of farm production that is transacted in the available market for agriculture". This definition constitutes both sides of the market. Accordingly, input commercialization entails the proportion of farm inputs purchased in the smallholder production process. Olwande et al. (2012), in turn, defined 'smallholder commercialization' in association with farm orientation. According to him, the concept is understood as "a process whereby subsistence production is transformed into market production". The later nutshell interpretation is usually mixed in its nature; a proportion is for household consumption; the rest goes to the market. There would be no complete transformation to market orientation in smallholder agriculture; otherwise, a benchmark should be incorporated in the definition. A definition widely used in empirical studies has been in line with (Katerega et al., 2018; Afework and Endrias, 2016; Moti et al., 2009), describing 'smallholder commercialization' as "the degree of involvement in the output/input markets relative to total input usage/production". Of course, this conceptualization can be viewed as a proportion of output produced/inputs purchased out of the total input used in the farm operation. From the side of the inputs market, 'smallholder commercialization' could be explained as a proportion of purchased agricultural inputs out of the total input used in the production operation. Accordingly, we followed (Katerega et al., 2018; Afework and Endrias, 2016; Moti et al., 2009) to define smallholder commercialization from the inputs side in this paper. We provide the detail later under the section for research methodology, particularly variables indexation.

\subsection{Study hypotheses}

The study tests the research hypotheses developed in accordance of research objectives. We tested the null hypotheses linking rural infrastructure to smallholder crop input market participation in Jimma zone. Specifically, we examine the bellow hypotheses:

- Smallholder access to rural all-weather road does not have significant effect on smallholders' agricultural commercialization from the crop inputs side.

- Agricultural Extension services do not significantly foster smallholder crop input market participation.

- There is no significant relationship between credit services and smallholder commercialization of farmers in Jimma Zone.

- There is no difference on the contribution of hard versus sift infrastructures to smallholder crop input market participation. 


\section{Research methodology}

\subsection{Description of the study area: Jimma Zone}

Geographically, Jimma zone is situated at South-West Ethiopia. Jimma Zone administration is composed of twenty one sub-lower administrative units, locally named, Woreda. The total of human population was reported to exceed three million under 516, 321 households in general, according to the official report from culture and tourism department in 2016/17. Jimma Zone is characterized by an agro-ecological setting of highlands (15\%), midlands (67\%) and lowlands (18\%). It is one among the major coffee growing areas in in Ethiopia, even claiming the legal recognition considering self being 'Land of Coffee Origin', though remained an issue of debate due to the same claim from other parts of the country. Jimma zone consistently receives favorable rains ranging from 1200-2800 mm per annum; this atmosphere is very comfortable to invest in the area of agro-industry as well as investments based on active community participation. The climatic condition of Jimma zone is characterizedby $15 \%$ highland, 67\% midlands and about 18\% lowlands (UNDP, 2016). Jimma is among the major coffee growing regions in the country. The area consistently receives good rain, ranging from 1200-2800 mm per annum. Therefore, this gives an opportunity to invest in agribusiness and grantees the feasibility of these projects in particular. Besides, Jimma city serves as the largest market center in South-West Ethiopia. With easy access to transportation and other necessities, Jimma serves adequate market center for potential investments in and around its geographical boundary. It has latitude and longitude of about $7^{\circ} 40^{\prime} \mathrm{N}$ and $36^{\circ} 50^{\prime} \mathrm{E}$, respectively. Jimma is characterized to exhibit tropical rainforest climate as of the Köppen climate classification. Temperature at Jimma ranges between $20^{\circ} \mathrm{C}$ and $25^{\circ} \mathrm{C}$ year-round range, on daily average. Below is an official map of Jimma Zone:

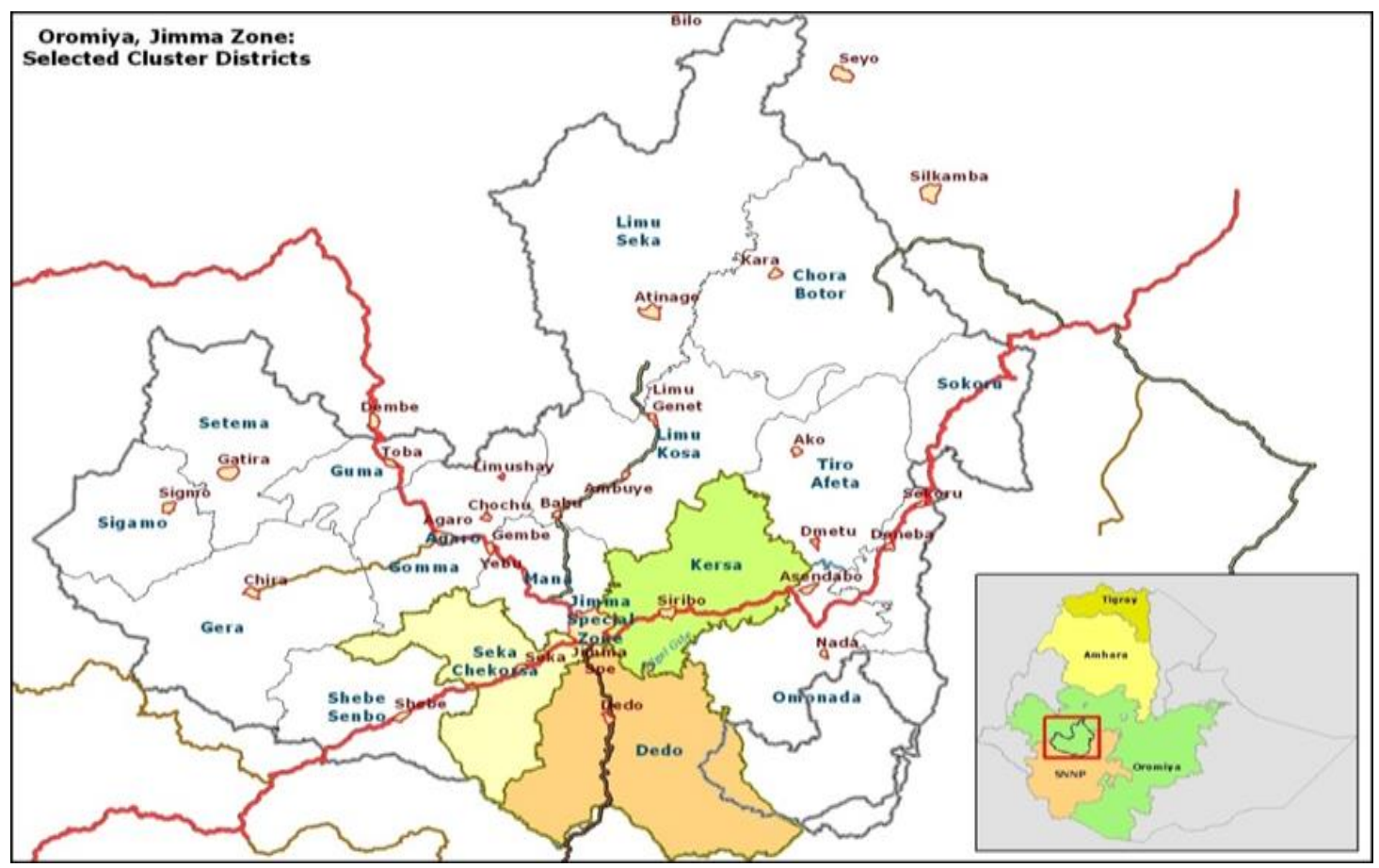

Source:(UNDP, 2016)

\subsection{The data: type, source, nature}

We used both primary and secondary data types. Primary data were sourced from the individual respondents included in the survey. Besides, we obtained secondary data from Jimma zone agriculture department, Finance and Economic Development office, and Trade Departments of the zone and respective woreda offices. The analysis is based on cross-sectional observations of sample smallholder households during 2018/19 production year. 


\subsection{Sampling: size and techniques}

Out of twenty oneworedas we arbitrarily selected six: Limmu Kossa, Gomma, Manna, Omo Nada, Tiro Afeta and Setema. Each woredawas further divided into sections based on kebele constituents, the lowest administrative unit. Random proportionate sample of kebelewas selected from each woreda. Finally, households were proportionally randomly drawn from each kebele administration. Therefore, the sampling procedure has passed through multiple stages.

According to official record from Jimma Zzone administration in 2017/18, the respective household size for each sample woreda is estimated at; 7,$343 ; 4,540 ; 4,818 ; 28,574 ; 17,442$ and 13,469 , added to give a total of 76,186 households. The appropriate sample size was determined following Yamane (1967) given by $\mathrm{n} \geq \frac{\mathrm{N}}{1+(\mathrm{N}-1)\left(\frac{2 \mathrm{~d}}{\mathrm{z}}\right)^{2}}=398$ (for $\mathrm{d}=0.05 ; \mathrm{Z}=1.96$ ). The sample was proportionally distributed across six sample woredas included in the survey.

\subsection{Data analysis:}

\section{(a) Crop Input Market Participation Index}

A conventional approach in measuring the household commercialization from input side is to take the ratio of the value of crop inputs purchased to the total value of crops produced in a particular production period (Katerega et al., 2018; Afework and Endrias, 2016; Moti et al., 2009; FAO, 2018). $\mathrm{We}$, however, argue that, such indexing is inappropriate from the conceptual point of view. Berhanu and Moti have of course gone through smallholder analysis in line with our indexation of CIMP (details on Moti and Birhanu, 2009). It is extremely misleading to imagine that every input used comes from some external source. For instance, a typical rural household in Ethiopia retains some portion of crops cultivated at a given production season, that would serve as input for the next production season. He or she then fills the likely input gap from external sources in the form of input purchase. Here we argue such indexation of crop input commercialization is highly weak. We then considered two aggregate values to index farmer's intensity of commercialization from the input side: value of crop inputs purchased and used. Our exposition here follows; households' obtain inputs from two sources; partly from their granary and the rest from market. Only the portion obtained from input market well explains the degree of market participation of the householders.

Following this conceptualization, we index the crop input market participation as the proportion of gross value of purchased inputs from the total value of crop inputs used in annual production. Therefore, we hoped our way best indexes the extent to crop input commercialization by smallholder households in Jimma Zone.

It is important to realize also that, a typical household may produce different types of crop, and hence use various combinations of crop inputs. Customarily it needs aggregation of values. We first need to value the total inputs used, both internal and external, by each household in annual crop production. Internal inputs could be valued at their current market prices. Besides, the amount of expenditure household incurred to buy different combination of external inputs in the annual crop production measures the total value of purchased crop inputs. This value can either be reported as final sum or we rather record individual figures and manipulate for aggregation. We expect market information on price and supply of relevant inputs from Jimma zone departments for trade and agricultural development.

Smallholders' agricultural commercialization from the input side is captured as the proportionate value of all crop inputs purchased to total values of crop inputs used in annual crop production season. Consequently, the crop-input market participation (CIMP) index to the present study is given by;

$C I M P_{i}=\frac{\sum_{\mathrm{k}=1}^{\mathrm{K}} \overline{\mathrm{P}}_{\mathrm{r}} \mathrm{L}_{\mathrm{ik}}^{\mathrm{P}}}{\sum_{\mathrm{k}=1}^{\mathrm{K}} \overline{\mathrm{P}}_{\mathrm{k}} \mathrm{L}_{\mathrm{ik}}^{\mathrm{T}}}$

Where, CIMP is crop input market participation for $\mathrm{i}^{\text {th }}$ household; $\mathrm{L}_{\mathrm{ir}}^{\mathrm{P}}$ is the amount of input $k$ bought each household at an average input price of $\overline{\mathrm{P}}_{\mathrm{r}}$. $\mathrm{L}_{\mathrm{ik}}^{\mathrm{T}}$ is the total quantity of input $r$ used by each household in annual crop production. 


\section{(b) Censored Tobit Specification}

The CIMP index, the response variable of this particular analysis, is categorical in nature. Thus, we will be adapting a discrete choice dependent regression models to estimate the impact of rural infrastructure on smallholder commercialization from the input side. Another thing to note is that, we cannot assume every sample observation to involve in the purchase of crop inputs during annual production. Its statistical implication follows that, information on the degree of input commercialization for some observation would be missing. It is actually empirical fact in Ethiopia to observe a weak or even no participation of most smallholders in crop input markets. Few of them used to purchase only crop inputs in case of inadequate reserves from previous harvest season. In case of adequate amount of stocks in their granary, they could no longer participate in the input market to purchase other farm inputs. Related to various socio-economic and other technical factors, most smallholders in Ethiopia are highly reluctant to adopting farm technologies. A case of fertilizer adoption best explains such phenomenon in the country. An important point here follows is, it makes no sense to expect entire set of information on CIMP by all sample observation while modeling its relationship with rural infrastructure. Data would be available only for some of the sample observation (households); hence, we have censored observation. This further necessitates estimation of censored regression model to quantify the impact of rural infrastructure on smallholders input market participation. Censored Tobit is suitable approach to appropriately model such relationships in the context of the present survey. Following Gujarati (2004), Censored Tobit can be specified as follows;

$\mathrm{y}_{\mathrm{i}}^{*}=\mathrm{x}_{\mathrm{i}}^{\prime} \beta+\varepsilon_{\mathrm{i}}$

$$
\mathrm{y}_{\mathrm{i}}=\left\{\begin{array}{l}
0, \text { if } \mathrm{y}_{\mathrm{i}}^{*} \leq 0 \\
1, \text { if } \mathrm{y}_{\mathrm{i}}^{*}>0
\end{array}\right\}
$$

Where $N$ is the number of observations, $y_{i}$ is the dependent variable (proportion of crop input purchased by smallholder $i$ in the observation period); $x_{i}$ is a vector of independent variables; $\beta$ is a vector of estimable parameters, $\beta \mathrm{x}_{\mathrm{i}}$ denotes the scalar product of two vectors, and $\varepsilon_{\mathrm{i}}$ is normally and independently distributed error term with zero mean and constant variance $\sigma^{2}$, i.e. $\varepsilon \sim \mathrm{N}\left(0, \sigma^{2}\right)$.It is assumed to be an implicit, stochastic index (latent variable) equal to $\mathrm{y}_{\mathrm{i}}{ }^{*}$ which is observed only when positive.

Our empirical guideline is adapted from Newbery (2012) and Osmani et al. (2015). We model the relationships using Tobit framework accordingly. The likelihood function over zero observation (0) and positive observations (1) can be expressed as;

$$
\log \mathrm{L}=\sum_{\mathrm{i}=1}^{\mathrm{N}}\left[\mathrm{I}_{\mathrm{i}}^{\mathrm{a}} \log \Phi\left(\frac{\mathrm{a}-\mathrm{x}_{\mathrm{i}}^{\prime} \beta}{\sigma}\right)+\mathrm{I}_{\mathrm{i}}^{\mathrm{b}} \log \Phi\left(\frac{\mathrm{x}_{\mathrm{i}}^{\prime} \beta-\mathrm{b}}{\sigma}\right)+\left(1-\mathrm{I}_{\mathrm{i}}^{\mathrm{a}}-\mathrm{I}_{\mathrm{i}}^{\mathrm{b}}\right)\left(\log \varnothing\left(\frac{\mathrm{y}_{\mathrm{i}}-\mathrm{x}_{\mathrm{i}}^{\prime} \beta}{\sigma}\right)-\log \sigma\right)\right]
$$

Where $\phi($.$) and \Phi($.$) , respectively, represent the probability density function (pdf) and the cumulative$ distribution function of the standard normal distribution; $\mathrm{I}_{\mathrm{i}}^{\mathrm{a}}$ and $\mathrm{I}_{\mathrm{i}}^{\mathrm{b}}$ are indicator functions each with:

$\mathrm{I}_{\mathrm{i}}^{\mathrm{a}}=1$, if $\mathrm{y}_{\mathrm{i}}=\left\{\begin{array}{lr}\mathrm{a} & \mathrm{I}_{\mathrm{i}}^{\mathrm{b}}= \\ 0, & \text { if } \mathrm{y}_{\mathrm{i}}>\mathrm{b}\end{array}\right\} \quad 1, \quad$ if $\mathrm{y}_{\mathrm{i}}=\mathrm{b}$

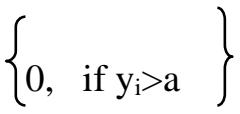

Maximum Likelihood (ML) approach for censored regression model is regarded as the Tobit model in the present analysis; and ML Tobit was analyzed using the software package for STATA version 14. The main benefit of using this model is that it produces consistent estimate of standard errors and can easily be used to test statistical significance of the parameters (Gujarati, 2004; Wooldridge, 2003).

CIMP is modeled as a function of gender characteristics of the householder (Sex), age of HH head (Age), education of the householder (Educ.), household labor (Labor), non-farm income (Income), radio-ownership (radio), distance to nearest all-weather rad (Road), access to credit (Crdt), distance to 
nearest market (mkt), extension services (Ext), livestock (livstk), and market orientation (mktornt) as follows;

$\mathrm{CIMP}_{\mathrm{i}}=\mathrm{f}$ (sex, age, Educ, hh labor, non-farm income, radio, Road access, mkt access, credit, ext, livstk, mktornt, $\mathrm{u}_{\mathrm{i}}$ )

\subsection{Variables definition and expectation}

Table 1: Description of Explanatory Variables and Expected Effect

\begin{tabular}{|c|c|c|c|}
\hline Variable/Attribute & Variable Type & Variable Measurement & Expectation \\
\hline Sex of HH head & Dummy & 1 if household head is male, otherwise 0 & $+/-$ \\
\hline Age of $\mathrm{HH}$ head & Continuous & Age of the household head (years) & + \\
\hline Level of Education & Continuous & Formal education of the household head (years of schooling) & + \\
\hline Mkt distance & Continuous & Amount of land under cultivation of farm household & - \\
\hline Household labor & Continuous & $\begin{array}{l}\text { Number of active family members working on the family farm } \\
\text { (aged } 15-60 \mathrm{yrs} \text { ) }\end{array}$ & + \\
\hline Non-farm income & Continuous & $\begin{array}{l}\text { Total income earned from non-farm activities in the production } \\
\text { year }\end{array}$ & + \\
\hline Radio ownership & Dummy & 1 if a household owns and 0 otherwise & + \\
\hline Road distance & Continuous & Distance in kilometers from the nearest all-weather road & \\
\hline Extension services & Dummy & $\begin{array}{l}1 \text { if a household involved in extension services the last year, and } \\
0 \text { otherwise }\end{array}$ & + \\
\hline Access to Credit & Continuous & Amount in birr of financial loan previous year & + \\
\hline Livestock & Dummy & 1 if a household also produce tropical livestock and 0 otherwise & + \\
\hline Market orientation & Dummy & $\begin{array}{l}1 \text { if the farmer's production is more of market oriented, and } 0 \\
\text { otherwise }\end{array}$ & + \\
\hline
\end{tabular}

\section{Results and Discussion}

\subsection{Descriptive information}

Here we present the descriptive statistics of variables entered the censored Tobit regression, and highlight the implication with each figure.

Table2: Descriptive information of the variables entered the Tobit regression

\begin{tabular}{|c|c|c|c|c|c|}
\hline Variables & Obs. & Mean & Std. Dev. & Min. & Max. \\
\hline Crop input market participation index & 398 & 10.29 & 14.694 & 0 & 87 \\
\hline Value of crop inputs used (ETB) & 398 & 1234.215 & 725.245 & 0 & 4751.34 \\
\hline Value of crop inputs purchased (ETB) & 398 & 253.106 & 521.214 & 0 & 3137.45 \\
\hline Age of the household head & 398 & 46.82 & 11.814 & 26 & 82 \\
\hline Household labor supply & 398 & 5.00 & 1.953 & 1 & 9 \\
\hline Non-farm income ( $1=$ exists $)$ & 398 & 0.713 & 0.453 & 0 & 1 \\
\hline Radio ownership $(1=$ owns $)$ & 398 & 0.50 & 0.501 & 0 & 1 \\
\hline Distance to nearest all-weather road & 398 & 4.39 & 5.131 & 0.1 & 8.5 \\
\hline Distance to nearest market place & 398 & 4.24 & 5.899 & 0.02 & 9.8 \\
\hline Agricultural ext. ( $1=$ consulted last year $)$ & 398 & 0.93 & 0.257 & 0 & 1 \\
\hline Livestock production $(1=$ producing $)$ & 398 & 0.90 & 0.293 & 0 & 1 \\
\hline Market orientation $(1=$ Oriented $)$ & 398 & 0.91 & 0.282 & 0 & 1 \\
\hline Size of credit previous year & 398 & 3714.27 & 1008.021 & 0 & 8000 \\
\hline Education (years of schooling) & 398 & 3.45 & 4.760 & 0 & 12 \\
\hline
\end{tabular}

Source: (Own Survey, 2018/19)

An average crop input market participation index is about 11 percent signifying low participation rate in the study area. The computed average index for crop input market participation by smallholder farming is 10.29 , while the minimum and maximum indexes area 0 and 87 percentages, respectively. This huge difference implies considerable variability across individual farmers with regard to their status in involving in the crop input markets as purchasers. Overall, the calculated mean index shows the lowest degree of crop input market participation by the smallholder farmers around Jimma zone. 
This can farther be confirmed from the maximum and minimum values of crop inputs applied in the annual crop production, both from the external and internal sources.

The average value of crop input used for annual crop production is estimated at 1,234.215 birr, of which about 253.106 birr come from external markets in the form of purchased inputs. That is, on average value of about 20.51 per cent only is purchased input in the production of annual crop production in the study area, indicating a very low proportion of purchased crop inputs. These figures are obvious to Ethiopian agriculture, since most smallholder farmers rely more on the use of internal resources as own family labor, seeds reserves from previous harvest year for current production, home based composts and the like. Only relatively advanced farmers purchase improved seeds, chemical fertilizers on demand, and other sophisticated farm technologies. However, the proportion of purchased inputs appears to be very low, since majority are reluctant to purchase crop inputs considerably due to economic and technical as well as institutional reasons. The average household labor supply is about 5 persons per head, with a minimum of 1 and maximum of 9 workers each case, indicating moderate availability of workers actively serving own farm irrespective of to what extent the quality of labor supply is. Generally speaking, labor quality can be noted out in reference to the average years of schooling which is suggested to be about 3 years. However, the computed average years of school enrolment is very low compared to the country's minimum standard for basic education. Thus, the household labor supply though moderate in quantity, is less efficient due to inadequate education.

About 155(38.94 per cent) of the household in the study area is headed by female, indicating the paramount role of women in managing the household and making farming as well as marketing decisions. Though the proportion is less compared to their male counterparts, still the revealed share is considerable.

About 93 percent households in the sample involved in agricultural extension programs the previous year, indicating that they are better aware on the likely positive effect of general knowledge for farming practices. Besides, the agricultural service providers are effective in reaching more households, though the estimated impact of extension service on smallholder commercialization was insignificant. This may, in turn, be due to service inefficiency, service inadequacy, or even inadequate factors from the users' side (Barrett, 2014; Sourovi et al, 2012; Mtigwe et al, 2013). This particular finding implies that, it is service quality that matters more in enhancing the commercial transformation of subsistence agriculture.

\subsection{Inferential analysis: Censored Tobit Estimation}

Before we run regression on censored Tobit, we examined the validity and reliability conditions and none of them was suggested invalid. Below is the Stata 14 front page display for our regression of the censored Tobit:

Table3: Factors affecting smallholders' crop input market participation

\begin{tabular}{lcc}
\hline Explanatory Variables & Coef. & Prob. \\
\hline Sex of household head (Female = 1) & -0.0470501 & 0.036 \\
Age of household head & -0.0018209 & 0.174 \\
Education of household head & 0.0214895 & 0.000 \\
Active household farm labor & 0.0668203 & 0.000 \\
Non-farm income & 0.2302946 & 0.000 \\
Radio ownership (1= ownership) & 0.0461459 & 0.042 \\
Distance from nearest all-weather road & -0.0374712 & 0.000 \\
Agricultural extension (1=if consulted) & 0.0213435 & 0.859 \\
Livestock production (1 = produce) & -0.0102509 & 0.870 \\
Orientation (1 = cash crop, $0=$ non-cash) & 0.1208748 & 0.108 \\
Amount of financial credit previous year (ETB) & 0.0000594 & 0.000 \\
Distance from nearest town (market center) & -0.0328414 & 0.000 \\
\hline \multicolumn{2}{c}{ Number of obs. = 380 } & LR Chi2(12) \\
\hline
\end{tabular}

Source: Own survey $(2018 / 19)$ 
Evident from table 3 significant and relevant role of infrastructure services to intensifying smallholder commercialization. We see that, Household participation in yearly crop inputs purchase market is influenced by household heads' gender and education, family labor supply, participation in off-farm activities, market orientation, access to all-weather road, and access to finance. With an exception to ambiguities in some variables, all others have expected signs.

Distance to the nearest all-weather road lessens smallholder farmers' participation into crop input market as a buyer, due to its implication with increasing transportation and other transactions costs. Left censored Tobit regression results (table 3) evidence that, for every $\mathrm{km}$ distance in the households' settlement area from the nearest all-weather roads, the household participation into the crop input market detracts on average by about 0.034 (0.000), which is found to be strongly significant response from the market side. Being far from the main road has negative effect on crop input market participation since transportation costs are likely to complement access to road. Distance from the transport facility, due to its unfavorable effect on decision of farm, influences producers consent to purchase farm inputs, and hinders them from involving into the market. Very large distance from the main road is likely associated with higher transport costs, which in turn, potentially reduces the efficiency of farm operation. Inefficient farm operations tend to be highly sensitive to potential risks, and farmers become reluctant of making risky decisions. As a result, production will be oriented to home use and their participation into the market, both as sellers and buyers, will be very low. It gives empirical support to most recent studies such as those of (Poole et al., 2013; Mtigwe et al., 2013; Osmani et al., 2015; Katerega et al., 2018; Goshu et al., 2012; Kabiti et al., 2015; and Chirwa and Matita, 2012), among others.

As expected, distance to the nearest market place was a powerful deterrent of smallholder participation into crop inputs market, since production decisions are influenced by accessibility of marketing signals. Every farther kilometer from the nearest market reduces households' participation by an average factor of 0.33 (table 3); and that response was strong. Rational firms scrutinize efficiency in advance, both from production and distribution segments. Farther distance from the nearest market place is more likely associated with higher transactions costs (FAO, 2018; Chirwa and Matita, 2012; Chanyalew et al., 2011; Afework and Endrias, 2016; Egbetokun and Monona, 2012); in turn, reflected by higher prices. This has an important implication with the demand as well as welfare aspect of the market. Being far from the nearest market center reduces the likelihood of smallholder participation in the inputs market, as higher distances are meant to increase shipping costs. A farmer may be unenthusiastic of producing marketable goods fearing these firm-specific costs. Firms with lower transport costs may charge lower prices and vice versa. With subsistence orientation, there would be no way to purchase modern farm inputs externally. Therefore, access to markets has an important implication with the smallholder farmer crop input market participation as a purchaser. Conceptually, our finding is sound and empirically consistent with (Chirwa and Matita, 2012; Dorsey, 2017; Goletti, 2015; Justus et al., 2015; Egbetokun and Monona, 2012; and Katerega et al., 2018).

Provision of credit fosters smallholder participation into crop input markets as purchasers, since enhanced financial capability has positive implication with farmers' purchasing power. Other things constant, more increased access to finance is likely to increase the proportion of purchased inputs (Goletti, 2015; Birhanu and Moti, 2009; Egbetokun and Monona, 2012; Kabiti et al., 2015; Ogutu et al., 2017). We put a caution here that, farmer's buying decision is not absolutely expounded by financial competency, as production is also subject to natural as well as environmental shocks. Assuming stable system in farm operation, buying decisions are positively interrelated with financial capacity. Finance is the most persecutor of Ethiopian agriculture. Smallhold farmers usually get cash only during harvest period. Thus, they face shortage of cashes to purchase external inputs to complement internal resources. Provision of credits together with agricultural extension and entrepreneurial skills would be vital to enhancing rural development through fostering smallholder commercialization. Many empirical evidences such as (Osmani et al., 2015; Rosewell, 2010; Qaim and Ogutu, 2018; Pingali et al., 2019; Kabiti et al., 2015; Moti et al., 2009), of the many lists, acknowledged the role of credit service to foster smallholder commercialization in agriculture. The results were found to applicable in both markets; i.e., the inputs and outputs markets. 
Access to information thru radio channels for the study area was advocated effective. Evident from table 3 is the equitably significant and positive coefficient for the information variable, demonstrating differential effect of owning radio on households' participation into the crop input markets as buyers. Other things constant, radio owners' involvement into the market mentioned is 0.046 times better than those who do not, and the computed difference was economically eloquent. Those with radio can access marketing information from different radio channels transmitted around the study area, of which three come from national broadcast (Ethiopian radio services), FM 98.1 (Fana broadcasting corporation Jimma center), and Jimma University Community based radio services. These media transmissions provide regular marketing information such as prices, innovations, demand and supply conditions as well as other relevant issues. Access to the prevailing timely marketing information is crucial to analyze the general business environment and improving the forecasting efficiency for the firms (Chirani and Effatdoost, 2013); Sourovi et al, 2012). This finding validates theories favoring the relevance of information symettry for market efficiency. Moreover, household heads' education is significantly associated with household involvement in crop market. Education status was found to positively associate with smallholders' market participation from the input side. This positive relationship is theoretically obvious; and empirically in line with (Ele et al, 2013; Chirwa, 2012; Moti and Birhanu, 2009; Afework and Endrias, 2016; Chanyalew et al., 2011; Egbetokun and Monona, 2012). With education peoples' analytical skill improves (Chirwa, 2012), forecasts appear to be near to perfect (Barrett, 2014), technical and allocative efficiencies are enhanced (Chirwa, 2012; Barrett, 2014). An implication therefore follows that, the household's participation to crop input commercialization as a buyer improves with better education, due to its positive impulses of which a little is as suggested by the above authors.

Active family labor is significantly associated with household participation as a buyer into crop input market. For every additional active family labor supply, the household's degree of market involvement improves on average by a rate of 0.067 (table 3 ), which as indicated is a substantial contribution. This finding is more likely, especially to Ethiopia, where family labor is complementing external input. Due to the primitive technology in the Ethiopian agriculture, farm practices are based mostly on family labor, which in turn, is unskilled and less trained (Moti et al., 2009; Goshu et al, 2012; Goletti; 2015). Citrus paribus, an additional person to a particular family's farm plot is expected to advance the family's degree of input commercialization, on average by about 6 percent. Besides, an individual person's contribution in reference to family stands has been suggested economically meaningful too.

\subsection{Hard versus soft infrastructures: comparative relevance}

We do have basically two forms of investments with reference to agriculture (Ulimwengu et al, 2009; Egbetokun and Monona, 2012). These include investments for agriculture and investments in agriculture. While hard infrastructures constitute investments for agriculture, as for example, investments in rural roads, telecommunication, rural health and etc., soft infrastructures constitute investments in agriculture; like $R \& D$, agricultural extension services, irrigation projects, policies related to product distribution, etc. Some authors claim that investments in hard infrastructure (roads, communication and energy supply) are necessary, but not sufficient for effective market amalgamation. They further attest for the stipulation of soft infrastructure as key not only to the lessening of costs, but also to the provision of quality products. Still some others favor more investments in hard infrastructures with reference to rural development and smallholder commercialization as well.

Table 4: Left Censored Tobit Estimates: Hard versus Soft Infrastructures for CIMP

\begin{tabular}{lll}
\hline Explanatory Variables & Coef. & Prob. \\
\hline Distance from nearest all-weather roads & -0.0374712 & 0.000 \\
Agricultural Extension & 0.0213435 & 0.859 \\
\hline
\end{tabular}

Source: (Own Survey, 2018/19)

While distance to the nearest all-weather road from the smallholders' settlement is proxy to hard infrastructure, soft infrastructure has been represented by agricultural extension services. From the results in table 4, the estimated coefficient for distance to all-weather roads being - $0.0374712(0.000)$ 2020 | International Journal of Financial, Accounting, and Management/ Vol 2 No 3, 185-197 
is negative and strongly significant from the statistical point of view. It demonstrates that, access to road has meaningful implication with smallholders' decision to participate in the crop market from the input side. A negative association between road access and market participation describes that, smallholders far from the rural road are less likely to participate in the crop input market as buyers and vice versa. Thus, households' degree of commercialization varies inversely with their distance in kilometers from the nearest rural all-weather road. The positive impulse from road accessibility fosters smallholder commercialization in a number of ways. Access to road gives increases access to markets, integrates different market areas, alleviates risks for which the rural poor are often exposed to, and improves welfare arising from enhanced access to basic social services (Kabiti et al., 2015; Justus et al., 2015; Chan et al., 2009; Osmani et al., 2015; Newbery, 2012).

Unfortunately, the coefficient for agricultural extension service is insignificant, implying that the service being actually provided in Jimma zone is not effective, or didn't hit the target.Yet, it doesn't necessarily imply that agricultural extension services are irrelevant to rural development, but the estimated insignificant coefficient may be due to inadequacy of the service, which may in turn be due to lack of adequate knowledge among service providers, low farmers' awareness, time and condition aspects of the service provision. Generally, efficient rural development services are argued to improve the production as well as managerial skills, which in turn more productions. As a result, more production demand more input usage and allows farmers to purchase more external farm inputs. Despite its suggested positive impulse, we estimated the insignificant impact of soft infrastructures on smallholder commercialization from the input side.

\section{Conclusion and some policy implications}

Smallholder commercialization is crucial to ensuring the development needs of, particularly emerging economies, like Ethiopia. Commercial transformation of smallholder farming involves decisions based on market signals and the use of agricultural inputs. Thus, there is a need to emphasis the inputs side of agricultural market. We examined the effect of rural infrastructure on smallholder crop input market participation, using annual cross section for 380 rural households from Jimma zone. Accordingly, distance from nearest all-weather road to the household settlement area was found a significant deterrent to smallholder participation to crop input markets as purchasers, due to its implication with high transportation costs for shipping goods and services. This conclusion is similar to (Poole et al., 2013; Mtigwe et al., 2013; Osmani et al., 2015; Katerega et al., 2018; Goshu et al., 2012; Kabiti et al., 2015; and Chirwa and Matita, 2012). It suggests the provision of improved transportation, including rural roads, for enhanced commercial transformation of the sector in the study area. Other things constant, input demands are directly related to firm productivity; which, in turn, is influenced by availability of necessary infrastructures. Transport facilities are of prerequisites in farm decisions. Due its important implication with increased transport costs, distance to the nearest market place is also a significant constraint to smallholder participation to crop input market as a buyer, implying also that enhanced access to markets, both inputs and output, enhanced the smallholder participation into the crop input market as well as commercial transformation of the sector. Effects of both distances (market and all-weather road) are reflected via their important implication with the cost of transportation. Therefore, improved access to transportation would automatically resolve inadequate impulses from road and market accesses. It is necessary to look for alternatives that is efficient in serving the rural people; as stressed by (Chirwa and Matita, 2012; Dorsey, 2017; Goletti, 2015; Justus et al., 2015; Egbetokun and Monona, 2012; and Katerega et al., 2018)), among others in the literature.

Extension services were revealed ineffective despite conventional expectation. Due to its anticipated role in maintaining the attitude of commercialization among the smallholders, extension services are expected to foster commercialization through market linkages. Due to (Chanyalew et al., 2011; Chirwa and Matita, 2012; Goshu et al, 2012; Barrett, 2014), the insignificant effect of extension service calls for an effective and successful intervention to improve those extension services among the rural people in order to realize all of its positive impulses towards improving the smallholder crop input market participation in the study area. The differential effect of being radio owner was suggested favorable due to its important implication to information source. Interventions intensifying rural access to information are vital. 


\section{Limitations and suggested space for future}

This study is limited to a year data, where we are unable to estimate the long term impact of rural infrastructural service on rural commercialization. However, in cross-sectional studies, like this present one, a year data is sufficient to capture the patterns of various variables as well as their relationships, which enables us develop ways to plan for the long term dynamics. But, we suggest future studies to take a sufficient panel observation to fully model these relationships and reasonably infer outside the study area.

\section{Acknowledgements}

We thank Jimma University for funding this research project.

\section{References}

Afework, H., \& Endrias, G. (2016). Review on smallholder agriculture commercialization in Ethiopia: What are the driving factors to focus on? Journal of Development and Agricultural Economics, 8(4).

Barrett. (2014). Smallholder market participation: concepts and evidence from Eastern and Southern Africa. Food Policy, 299-317.

Chan, C., Forwood, D., Roper, H., \& Sayers, C. (2009). Public infrastructure financing: international perspective. Working Paper for Productivity Commission.

Chanyalew, S., Tesfaye, L., \& Karippai, R. (2011). Factors determining the degree of smallholder commercialization in agriculture: the case of potato growers in Kombolcha District, East Hararghe, Ethiopia. Institute of Development Studies.

Chirani, E. \&, Effatdoost, M. (2013). Diversification strategy, a way towards the competitive advantage. Arabian Journal of Business and Management Review, 3(1)

Chirwa., \& Matita. (2012). From subsistence to smallholder commercial farming in Malawi: a case of NASFAM Commercialization Initiatives. Brighton, UK, Working Paper

CSA. (2016). Socioeconomic survey 2015-2016. Report Paper, Wave 3, Ethiopia, 2015 - 2016

Dorsey, B. (2017). Agricultural intensification, diversification and commercial production among smallholder coffee growers in Central Kenya. ISTOR, 75(2)

Egbetokun., \& Monona. (2012). Determinants of farmers' participation in food market in Ogun State. Global Journal of Science Frontier Research Agriculture and Veterinary Sciences, 12(1)

Ele, I., Omini, G., \& Adinya, I. (2013). Assessing the extent of commercialization of smallholding farming households in Cross River State, Nigeria. IOSR Journal of Agriculture and Veterinary Science, 4(2), 49-55

FAO. (2018). Policy coherence for agricultural transformation in African least developed countries. Working Paper, FAO and ECDPM, 2018.

Goletti. (2015). Agricultural commercialization, value chains and poverty reduction, making markets world better for the poor. Discussion Paper, Asian Development Bank.

Goshu, Kassa., \& Ketema. (2012). Measuring smallholder commercialization decision and interaction in Ethiopia. Journal of Economics and Sustainable Development, 3.

Gujarati. (2004). Basic econometrics. $4^{\text {th }}$ Edition. Tata Mc-Graw-Hill Publishing Company Limited, New Delhi: India.

Justus, O., Knerr, B., Owuor, G., \& Ouma, E. (2015). Agricultural commercialization and household food security: the case of smallholders in Great Lakes Region of Central Africa. Conference Paper, Milan, Italy

Kabiti, H., Chauke, P., \& Pfumayaramba, T. (2015). Determinants of agricultural commercialization among smallholder farmers in Munyati Area, Zimbabwe. Research Article, Journal of Human Ecology, DOI: 10.1080/09709274.2016.11906951

Katerega, Y., Nangoli, S., Ssekakubo, J., \& Masaba, A. (2018). Commercialization of smallholder farming: it's inclusive household welfare effects on smallholder farmers in Butaleja District. Journal of Poverty, Investment and Development, 46(1); ISSN 2422-846X.

MoARD. (2017). Ethiopia's agricultural sector policy and investment framework. Strategic Country Report, Addis Ababa, Ethiopia 
Moti, J., \& Birhanu, G. (2009). Commercialization of smallholders: is market participation enough?”. Joint $3^{\text {rd }}$ of AAAE and $48^{\text {th }}$ AEASA Conference, Cape Town, South Africa

Moti, J., Berhanu, G., \& Hoekstra, D. (2009). Smallholder commercialization in Ethiopia: processes, determinants and impact. Discussion Paper No.18, International Livestock Research Institute, Addis Ababa, Ethiopia

Mtigwe, B., Zhou, S. \& Minde, I. (2013). Smallholder commercialization for income growth and poverty alleviation in Southern Africa, AJAR, 8(22)

Newbery D. (2012). Energy and infrastructure. Working paper, LSE Growth Commission.

Ogutu, S., Qaim, M., \& Godecke, T. (2017). Agricultural commercialization and nutrion in smallholder farm households. Discussion Paper, Universität Göttingen.

Olwande, J., \& Mathenge, M. (2012). Market participation among the poor rural household in Kenya. Conference Paper, Tegemeo Institute, Egerton University, Kenya.

Osmani, D., Hossain, M., Khairul, I. and Bikash, G. (2015). Commercialization of smallholder farmers and its welfare outcomes: evidence from Durgapur, Bangladesh. Journal of World Economic Research, 119-126.

Pingali, P., Abraham, M., \& Aiyar, A. (2019). Enabling smallholder prosperity through commercialization and diversification. Book Chapter, Online version accessed on: http: //www.researchgate.net/publication/333097684.

Poole, D., Chitundu, M., \& Msoni R. (2013). Commercialization: meta-approach for agricultural development among smallholder farmers in Africa? Food Policy (August): 155-165.

Qaim, M., \& Ogutu, S. (2018). Effects of agricultural commercialization on multidimensional poverty: evidence from smallholder farmers in Kenya. International Conference Paper, University of Goettingen, Germany.

Rosewell, B. (2010). Planning curses: how to deliver long-term investment in infrastructure. Working Series, January 2010

Sourovi, D., Johann, K., Mariam, M., \& Julius O. (2012). Managing agricultural commercialization for inclusive growth in Sub-Saharan Africa. The Global Development Network, New Delhi.

Stewart, J. (2010). UK National Infrastructure Plan 2010. Working Papers, European Investment Bank

The World Bank. (2017). Smallholder commercialization and agribusiness development project (P153437). Restructuring Paper, Report No.: RES33231, Agriculture Africa

Timmer, C. (1997). Armers and markets: political economy of new paradigms. American Journal of Agricultural Economics, 79(2)

Ulimwengu, J., Headey, D., Funes, J., \& You, L. (2009). Paving the way for development?: The impact of transport infrastructure on agricultural production and poverty reduction in the Democratic Republic of Congo", Research Article, available at: https://www.researchgate.net/publication/239807435

UNDP. (2016): The future of food and agriculture: trends and challenges. Working Paper Rome, 2016

Wooldridge, J., (2003). Introductory econometrics: a modern approach. Mason, Ohio: South Western.

Yamane T. (1967). Statistics: an introductory analysis, $2^{\text {nd }}$ ed. New York: Harper and Row. 